ON THE ISSUE OF ORGANIZATION OF DISTANCE LEARNING IN THE DISCIPLINE "INFECTIOUS DISEASES" ДО ПИТАННЯ ОРГАНІЗАЦЇ̈ ДИСТАНЦЙНОГО НАВЧАННЯ 3 ДИСЦИПЛІНИ “ІНФЕКЦІЙН ХВОРОБИ"

Davydenko O.М./ Давиденко О.М. c.med.s., as.prof./ к.мед.н., доu. ORCID: 0000-0002-8897-8913 Myronyk O.V./ Мироник O.B. c.med.s., as.prof., / к.мед.н., дои. ORCID: 0000-0002-5717-7267

SPIN:5163-7385

Bukovinian State Medical University, Chernivtsi, Teatral'na Sq., 2, 58000 Буковинський державний медичний університет, Театральна площа, 2, 58000

Abstract. The paper considers the organization of the educational process in the discipline "Infectious Diseases" using distance learning. The advantages of distance learning in high school are described. Distance learning opens up completely new opportunities for creative selfexpression, finding and consolidating various professional skills.

Key words: infectious diseases, distance learning, student.

\title{
Introduction
}

The COVID-19 pandemic and quarantine made adjustments to the organization of the educational process at the Higher School. The use of the Internet makes it possible to send the required amount of information from teacher to student, regardless of their location. The organization of distance learning allows you to freely conduct discussions with other users of the network online and post information on Internet sites, making it available to all students. Modern information technologies make it possible to increase and improve the efficiency of the educational process. In this regard, education in higher education needs to be modernized and reformed.[3,4] The issue of developing the concept of distance education, using a variety of technologies, including blended learning technologies, is relevant. [1,2]

\section{The main text}

Distance learning in the discipline of "Infectious Diseases" at Bukovina State Medical University is conducted using the video conference service Google Meet. The organization of the educational process is based on the principles of open learning. Computer programs for various purposes are used and information educational environments are created with the help of modern telecommunications for the supply of educational material and communication.

Distance learning has a number of advantages over other forms of learning. Yes, virtually without leaving home or leaving your workplace, which is extremely important in a pandemic, you can maintain regular contact with the teacher through telecommunications technology, including video, and receive structured learning material presented electronically. In addition, electronic journals are available to students; on-line services for the educational process, communication, testing; library, media library; file storage; video conferencing; e-mail with the domain of the educational institution. In the study of the discipline "Infectious Diseases" 5th year 
students provided 105 hours. which are structured in 5 meaningful modules. Organizational-methodical and educational-reference blocks, as well as means of self-control and testing of students' knowledge of infectious diseases are covered on the MOODLE distance learning server.

Distance learning technologies in the discipline "Infectious Diseases" consist of pedagogical and information technologies. A characteristic feature of distance learning is flexibility. Students receiving distance education do not attend full-time classes, but study in a convenient place. The distance education program is based on the modular principle; each individual course creates a holistic view of a particular subject area, which allows a set of independent courses-modules to form a curriculum that meets individual or group needs.

Students have the opportunity to simultaneously access many sources of educational information, communicate through telecommunications with each other and with teachers.

The use in the educational process of new advances in information technology, which contribute to the entry of man into the world information space.

Due to such organization of the educational process, equal opportunities for education are created regardless of the place of residence, state of health and social status.

An important point is the international component of distance learning, in particular, the provision of educational services to foreign citizens and compatriots living abroad.

Distance education expands and renews the role of the teacher, makes him a mentor-consultant, who must coordinate the cognitive process, constantly improve the courses he teaches, increase creative activity and skills in accordance with innovations and innovations.

The quality of distance education is not inferior to the quality of full-time education, because the best teaching staff is involved in the preparation of teaching aids and the most modern teaching materials are used; the introduction of specialized quality control of distance education for compliance with its educational standards is envisaged.

The development of distance learning will continue and improve with the development of Internet technologies and the improvement of distance learning methods.

\section{Conclusions}

The issues of organization of the educational process in the discipline "Infectious Diseases" with the use of distance learning of students were considered. Distance learning provides graduates with access to non-traditional sources of information, increases the efficiency of independent work, provides completely new opportunities for creative self-expression, finding and consolidating various professional skills, and allows teachers to implement completely new forms and methods of teaching.

References:

1. Bikov V.Yu. Distance learning in Europe and the United States and prospects 
for Ukraine / V.Yu. Bykov // Information support of the educational process: innovative tools and technologies: col. monograph / V.Yu. Биков, О.О. Гриценчук, Ю.O. Beetle and others. / Academy of Pedagogical Sciences of Ukraine, Institute of Teaching Aids. - К.: Атіка, 2015. - С. 77-140.

2. Gurevich R.S. Interactive technologies of training in a higher pedagogical educational institution: textbook. manual / RS Gurevich, M. Yu. Kademiya, LS Shevchenko. - Vinnytsia: LLC firm "Planer", 2013. -309 p.

3. The concept of development of distance education in Ukraine (approved by the Resolution of the Ministry of Education and Science of Ukraine VG Kremen on December 20, 2000)

4. On the National Strategy for Education Development in Ukraine for the period up to 2021 [Electronic resource]: Decree of the President of Ukraine of 25.06.2013 № 344/2013. - Access mode: http://zakon2.rada.gov.ua/laws/show/344/2013

\section{Література:}

1. Биков В.Ю. Дистанційне навчання в країнах Європи та США і перспективи для України / В.Ю. Биков // Інформаційне забезпечення навчально-виховного процесу: інноваційні засоби і технології : кол. монографія / В.Ю. Биков, О.О. Гриценчук, Ю.О. Жук та ін. / Академія педагогічних наук України, Інститут засобів навчання. - К. : Атіка, 2015. - С. $77-140$.

2. Гуревич Р. С. Інтерактивні технології навчання у вищому педагогічному навчальному закладі : навч. посібник / Р. С. Гуревич, М. Ю. Кадемія, Л. С. Шевченко. Вінниця : ТОВ фірма «Планер», 2013. -309 с.

3. Концепція розвитку дистанційної освіти в Україні (затверджено Постановою МОН України В.Г. Кременем 20 грудня 2000 р.)

4. Про Національну стратегію розвитку освіти в Україні на період до 2021 року [Електронний ресурс] : Указ Президента України від 25.06.2013 № 344/2013. - Режим доступу: http://zakon2.rada.gov.ua/laws/show/344/2013

Анотація. В роботі розглядається питання організації навчального процесу 3 дисципліни “Інфекційні хвороби” з використанням дистанційної форми навчання студентів. Описані переваги дистанціийного навчання у вищій школі. Дистанціийне навчання відкриває абсолютно нові можливості для творчого самовираження, знаходження та закріплення різних професійних навичок.

Ключові слова: інфекиійні хвороби, дистанційне навчання, студент. 